\title{
ASPEK HUKUM WASIAT WAJIBAH UNTUK AHLI WARIS ANAK KANDUNG YANG BERBEDA AGAMA DALAM PUTUSAN MAHKAMAH AGUNG NOMOR 51 K/AG/1999
}

\author{
Wahyu Darmawan, \\ Universitas Singaperbangsa Karawang \\ Email : darmawan.wahyu83@gmail.com
}

\begin{abstract}
The barrier to inheritance or mawani 'al-irth is a barrier to the implementation of inheritance between the heir and his heirs. One of the barriers to the implementation of war is religious differences. Religious differences are one of the barriers that can cause a person to not be able to receive inheritance from someone who has died. The existence of these religious differences becomes a barrier to inheritance which has been explained based on a hadith of the Prophet Muhammad SAW: "It is not right for a Muslim to respect an infidel, nor do an infidel respect a Muslim" (HR Bukhari \& Muslim). Research Methods in this scientific papers using normative juridical research methods and using data collection techniques carried out using descriptive analysis techniques, with secondary data sources, which include primary legal materials such as laws and regulations relating to the rights of children and wives in divorce cases, sued unseen husbands, as well as secondary legal materials such as books, journals, articles, and other legal doctrines. From the results of the research that has been done, it can be concluded that the position of non-Muslim children on the inheritance of heirs who are Muslim is not as heirs because Islamic Inheritance Law does not recognize the existence of heirs to people of different religions (nonMuslims). However, according to the Panel of Judges and, according to Islamic inheritance law, heirs who are not Muslim, cannot be heirs, but because Islamic inheritance law in Indonesia contains an egalitarian principle, relatives who are religious other than Islam who have blood relations with the heirs can get the share of inheritance by using a mandatory will without exceeding the share of heirs who are equal to it, this is in accordance with the Decision of the Supreme Court.
\end{abstract}

\section{Keywords: Inheritance, Mandatory Will (Wasiat Wajibah), Heirs of different religions}

\section{PENDAHULUAN}

Permasalahan tentang kewarisan yang sampai saat ini menjadi suatu perdebatan dalam keluarga, yang sering menimbulkan akibat-akibat yang tidak menguntungkan bagi setiap anggota keluarga yang ditinggalkan. Padahal seperti yang sudah kita ketahui harta kekayaan semasa hidup tidak akan dibawa mati dan juga tidak akan ada gunanya lagi ketika kita sudah meninggal nanti. Harta kekayaan yang kita miliki merupakan suatu titipan oleh Allah SWT kepada umat manusia, sehingga sebagai pemenuh kebutuhan dan agar tidak lupa kepada yang Maha Pemberi. Namun pada kenyataanya harta kekayaan yang ditinggalkan oleh orang yang sudah meninggal, sering sekali menjadi suatu perdebatan dikalangan ahli waris maupun anggota keluarga. 


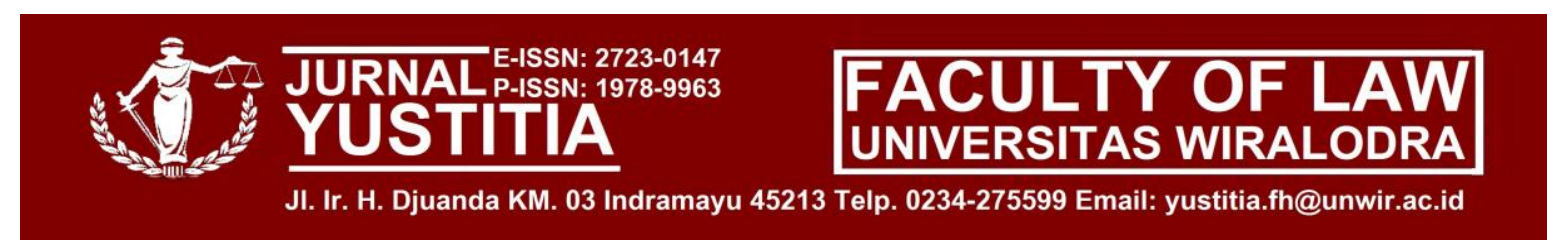

Setiap orang pasti akan mengalami sebuah peristiwa kematian, baik itu ditinggalkan ataupun meninggalkan. Apabila kematian tersebut terjadi, maka pasti akan menimbulkan suatu akibat hukum, yaitu tentang suatu solusi bagaimana kelanjutan pengurusan hak dan kewajiban seseorang yang telah meni nggal dunia. Di antara kewaji ban orang yang telah meninggal dunia perlu pengurusan oleh keluarga dekatnya yaitu mengenai waris dan wasiat ${ }^{1}$.

Dalam Kitab Undang-Undang Hukum Perdata ada dua cara untuk mendapatkan sebuah warisan, yaitu:

1) Sebagai ahli waris menurut Undang-Undang.

2) Karena ditunjuk dalam surat wasiat (testament).

Peralihan harta kekayaan dari seseorang yang telah meninggal ke orang yang diti nggalkan bisa dilakukan melalui sebuah wasiat, dalam Agama Islam wasiat sudah diatur didalam kitab suci Al-Qur'an dan Al-hadits. Sebuah wasiat tidak hanya diatur dalam Agama Islam saja, tetapi setiap agama tentunya sudah memiliki pemahan tersendiri tentang wasiat. Wasiat dapat diartikan sebagai pemberian harta peninggalan dari seseorang terhadap orang lain yang dilakukan setelah pemberi wasiat tersebut sudah meninggal dunia. Wasiat harus dilakukan dengan tidak adanya paksaan dari orang lain, dalam Agama Islam wasiat bisa dilakukan tanpa adanya putusan hakim² .

Perbedaan Agama merupakan salah satu penghalang yang dapat menyebabkan seseorang tidak bisa menerima harta warisan dari seseorang yang telah meninggal. Seperti yang terdapat dalam hadist, dalam hadits tersebut hanya bersifat anj uran dan bukan suatu perintah. Kompilasi Hukum Islam tidak mengatur secara pasti tentang hak pewarisan bagi keluarga yang berbeda agama. Sehingga saat ini masih menjadi topik yang selalu diperdebatkan dikalangan ulama maupun masyarakat. Berdasarkan uraian diatas penulis melakukan penulisan terhadap Hukum Islam, yaitu bagaimana pembagian harta waris dalam bentuk wasiat wajibah bagi ahli waris yang berbeda agama.

Dalam hadits diatas menjelaskan bahwa tentang permasalahan beda agama yang menjadi penghalang pembagian waris, yang apabila antar ahli waris dan almuwwaris salah satunya muslim dan lainnya non-muslim. Dalam hal ini tentunya harus adanya batasan tentang persoalan perbedaan agama yang di anut oleh ahli waris dan pewaris artinya

\footnotetext{
${ }^{1}$ Ahmad Azhar Basyir, Hukum Waris Islam, Yogyakarta: UII Press, 2001, hlm. 3.

${ }^{2}$ Habsi Ash-Shiddieqy, Fiqh Mawaris, Pustaka Rizki Putra, Semarang, 2001, hlm. 273.
} 
seorang muslim tidak akan mewarisi dari seorang nonmuslim begitu juga sebaliknya seorang non-muslim tidak mewarisi dari seorang muslim ${ }^{3}$.

Ada dua Putusan Mahmakah Agung tentang hak ahli waris non-muslim yaitu Putusan Mahmakah Agung Nomor : 368 K/AG/1 995 yang menyatakan bahwa ahli waris non-muslim mendapatkan bagian dari harta peninggalan pewaris muslim yang berdasarkan wasiat wajibah, yang dimana dalam putusan ini ahli waris nonmuslim tidak dinyatakan sebagai ahli waris, dan dalam putusan Nomor : 51 K/AG/1 999 bahwa ahli waris non-muslim tidak dinyatakan sebagai ahli waris dan mendapatkan harta warisan berdasarkan wasiat wajibah, dalam putusan ini ahli waris non-muslim tidak dinyatakan sebagai ahli waris, namun mendapatkan harta warisan dari pewaris muslim ${ }^{4}$.

Dalam putusan Nomor $721 \mathrm{~K} / \mathrm{AG} / 2015$ sudah jelas, bahwa Majelis Hakim telah memutuskan salah satu dari pewaris yang berbeda agama menjadi ahli waris. Hal ini sangat bertentangan dengan hukum Islam dan ketentuan-ketentuan dalam Kompilasi Hukum Islam (KHI) Pasal 171 huruf (c) yang menyatakan bahwa ahli waris harus beragama Islam saat pewaris meninggal.

Berdasarkan uraian di atas, maka penulis tertarik untuk mengambil judul penelitian mengenai "ASPEK HUKUM WASIAT WAJIBAH UNTUK AHLI WARIS ANAK KANDUNG YANG BERBEDA AGAMA DALAM PUTUSAN MAHKAMAH AGUNG NOMOR 51 K/AG/1999"

\section{IDENTIFIKASI MASALAH}

Berdasarkan latar belakang masalah diatas maka penulis dapat mengidentifikasi permasalahan sebagai berikut:

1. Bagaimana Aspek Hukum Wasiat Wajibah untuk Ahli Waris Anak Kandung yang beda Agama dalam Putusan Mahkamah Agung Nomor 51 K/Ag/1999.

\section{METODE}

Metode penelitian adalah langkah yang dilakukan dalam menambah kemampuan para ilmuwan untuk mengadakan atau melaksanakan penelitian secara lebih atau lebih

\footnotetext{
3 Ahmad Rafiq, Fiqh Mawaris, PT. Raja Grafindo Persada, Jakarta, 1993, hlm. 29.

4 www.menwih-hukum.blogspot.com "Perlakuan Waris Islam Non-Muslim". Diakses pada 22 Januari 2021, pukul 21.50 WIB.
} 
lengkap ${ }^{5}$. Metode penelitian bertujuan untuk memperoleh data mengenai hubungan antara suatu gejala yang lain dengan melakukan pendekatan penelitian apa, spesifikasi penelitian yang seperti apa serta jenis dan seumber data. Penelitian ini menggunakan pendekatan yuridis normative. Yuridis normative yakni pendekatan yang dilakukan berdasarkan bahan hukum utama dengan cara menel aah teori-teori, konsep-konsep, asas-asas hukum serta peraturan perundang-undangan yang berhubungan dengan penelitian ini. Pendekatan ini dikenal sebagai pendekatan kepustakaan, yakni dengan mempelajari buku-buku, peraturan perundangundangan dan dokumen lain yang berhubungan dengan penelitian ini $^{6}$.

Pada metode pendekatan ini penulis mengkaji permasalahan hukum berdasarkan aturan yang dikaitkan dengan kondisi yang dialami masyarakat. Sehingga pendekatan yang dilakukan dalam penelitian ini mengedepankan pendekatan yang dilakukan dengan melihat suatu kasus pembagian harta waris kepada anak dan istri yang berbeda agama.

\section{HASIL DAN PEMBAHASAN}

Bahwa almarhum Vincencius Papilaya meninggal pada tanggal 6 September 2013, yang dimana almarhum meninggalkan seorang istri bernama Sumarni binti Sirat dan meninggalkan dua orang anak dari hasil pernikahannya yang pertama yaitu Antonius Papilaya bin Vincencius Papilaya dan Fransisca Papilaya binti Vincencius Papilaya. Kedua anak Vincencius Papilaya dari hasil pernikahannya yang pertama meminta hak kepada Sumarni binti Sirat selaku ahli waris tunggal dari almarhum Vincencius Papilaya karena kedua anak almarhum merasa tidak mendapatkan haknya sebagai ahli waris anak kandung dari almarhum Vincencius Papilaya.

Antonius Papilaya dan Fransisca Papilaya meminta kepada Sumarti untuk membagi sebagian harta warisnya kepada meraka, yang dimana mereka masih mempunyai hak atas harta warisan tersebut. Tetapi dikarenakan Antonius Papilaya dan Fransisca Papilaya merupakan anak kandung yang berbeda agama, yang dimana sudah dijelaskan bahwa pewaris Muslim tidak dapat mewariskan harta warisannya kepada ahli waris yang berbeda agama, begitupun sebaliknya.

Dalam putusan Pengadilan Agama Palembang Nomor 1854/Pdt.G/2013 /PA.Plg menyatakan bahwa kedua anak Vincencius Papilaya dari hasil pernikahannya yang pertama

\footnotetext{
5 Soerjono Soekanto, Pengantar Penelitian Hukum, Universitas Indonesia (UI-Press), Jakarta, 2014, hlm. 7.

${ }^{6}$ Muhammad Abdulkadir, Hukum dan Penelitian Hukum, PT. Citra Aditya Bakti, Bandung, 2014, hlm. 65.
} 


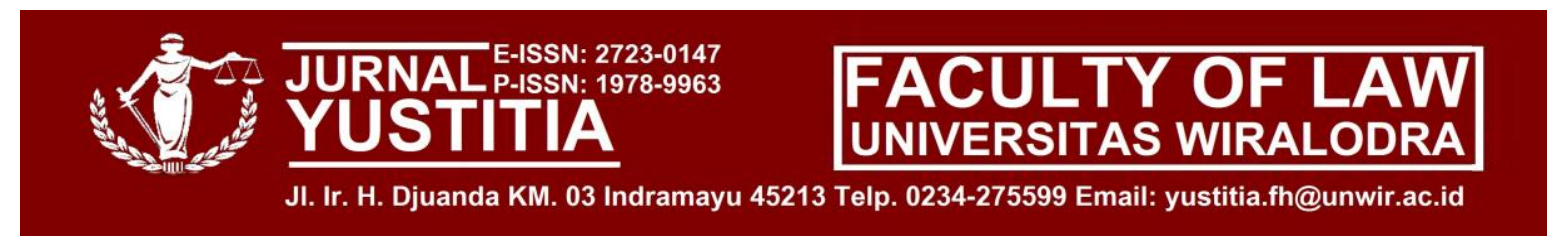

mengajukan permohonan pembagian harta waris dengan dalil obyek sengketa adalah harta warisan, peninggalan pewaris kandung dari Antoius Papilaya dan Fransisca Papilaya yang dimana harta warisan tersebut dipegang oleh Sumarni, meskipun kedua anaknya telah meminta haknya tetapi Sumarni tidak meresponnya, dan setelah dilakukan mediasi, hasilnya gagal, dan hakim telah berupaya untuk mendamaikan namun upaya mendamaikan tidak tercapai.

Majelis Hakim mempertimbangkan bahwa didalam Pasal 171 huruf b dan huruf c merupakan aturan bagi ahli waris yang sesuai dengan ketentuan, namun dalam perkara sebagaimana dalam putusan nomor 1854/Pdt.G/2013/PA.Plg, maka menurut Majelis Hakim, Hakim dapat keluar dari ketentuan aturan tersebut. Hal ini karena Hakim menggali perkara untuk menegakkan hukum dan keadilan. Menurut Majelis Hakim ahli waris yang tidak beragama Islam dan menurut hukum waris Islam, tidak dapat menjadi ahli waris, namun karena hukum waris Islam di Indonesia mengandung asas egaliter, maka kerabat yang beragama selain Islam yang mempunyai hubungan darah dengan pewaris, dapat memperoleh bagian waris dengan menggunakan wasiat wajibah dengan tidak melebi hi bagian ahli waris yang sederajat dengannya.

Pengadilan Tinggi Agama Palembang yang memeriksa dan mengadili perkara tertentu dalam tingkat banding telah menjatuhkan putusan dalam perkara gugatan warisan, dan menimbang, bahwa Sumarti binti Sirat selaku istri almarhum Vincencius Papilaya (pewaris) mendapat $1 / 8$ bagian dari harta warisan (1/2 dari harta gono gini) karena Pewaris meninggalkan dua orang anak yaitu Antonius Papilaya dan Fransisca Papilaya. Sesuai dengan Pasal 193 Kompilasi Hukum Islam (KHI), Sumarti selaku istri almarhum serta Antonius Papilaya dan Fransisca Papilaya mendpapatkan 1/3 bagian dari harta warisan sesuai juga dengan putusan Mahkamah Agung Nomor 51K/AG/1999 dengan cara wasiat wajibah.

Didalam hukum Islam seorang Muslim tidak dapat mewarisi atau diwarisi oleh orang non Muslim, apapun agamanya. Hal ini telah ditegaskan oleh sabda Rasulullah Saw, bahwa "Seorang Muslim tidak dapat mewarisi (harta) orang kafir, dan orang kafir tidak dapat mewarisi (harta) orang muslim.” Para ulama sepakat bahwa seorang yang beragama selain Islam tidak bisa mewarisi harta dari seseorang yang beragama Islam, begitu pula sebaliknya orang yang beragama Islam tidak berhak atas warisan orang yang beragama 


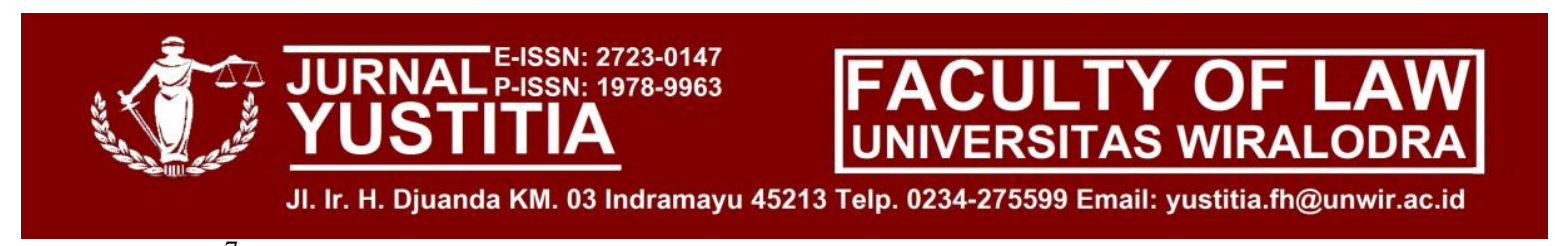

selain Islam ${ }^{7}$. Dengan demikian, ketika pewaris yang seorang Muslim meninggal dunia, maka ahli waris yang non muslim tidak dapat mendaparkan haknya karena adanya penghalang perbedaan agama. Seorang anak yang berbeda agama atau berpi ndah agama dengan orang tuanya tidak berhak atas warisan orang tuanya ${ }^{8}$.

Kompilasi Hukum Islam menegaskan bahwa "perbedaan agama antara pewaris dan ahli waris menjadi penghalang untuk saling mewarisi”, tetapi dalam yurisprudensi Mahkamah Agung Republik Indonesia telah memberikan hak kepada ahli waris muslim dari pewaris non-muslim ${ }^{9}$.

Ada perbedaan pendapat di kalangan ulama terkait waris beda agama. Sebagian ulama mengatakan bahwa ahli waris muslim tetap mendapat harta warisan dari pewaris yang kafir. Mayoritas ulama menyikapi dua permasalahan pertama di atas telah consensus, dalam hal ini Abu Hanifah, Malik, Syafi'i, dan para pengikutnya bahwa tidak boleh orang kafir mewarisi tirkah orang muslim, atau sebaliknya, apakah disebabkan karena hubungan memerdekakan budak (alwala'), hubungan perkawinan (al-zaujiyyah), dan/atau hubungan kekerabatan (alqarabah).

Demikian juga jika ada seorang muslim meninggal dunia, ia meninggalkan seorang isteri non muslim (al-kitabiyah), atau kerabat non muslim kemudian mereka masuk Islam sebelum tirkah al-muwarrits dibagikan, maka mereka tetap tidak mendapatkan hak waris ${ }^{10}$.

Terkait dengan hak waris berbeda agama, Kompilasi Hukum Islam merujuk pada pendapat para ulama yang menegaskan bahwa "perbedaan agama antara pewaris dengan ahli waris menjadi penghalang terjadinya proses kewarisan”. Hal ini sebagaimana diatur dalam Pasal 171 huruf b Kompilasi Hukum Islam yang menyatakan bahwa: "pewaris adalah orang yang pada saat meninggalnya atau yang dinyatakan meninggal berdasarkan putusan pengadilan beragama Islam, meninggalkan ahli waris dan harta peninggalan”.

Selanjutnya didalam Pasal 171 huruf c dinyatakan bahwa: "ahli waris adalah orang yang pada saat meni nggal duni a mempunyai hubungan darah atau hubungan perkawinan dengan pewaris, beragama Islam dan tidak terhalang karena hukum untuk menjadi ahli

\footnotetext{
7 Muhammad Ali Ash-Shabuni, “Pembagian Waris Menurut Islam”, Gema Insani Press, Jakarta, 1995, hlm. 43.

8 Zakiyah Salsabila, “Kewarisan Beda Agama menurut Hukum Waris Islam dan Hukum Waris Adat”, Jurnal UIN Syarif Hidayatullah.

9 Rohmawati, "Progresivitas Hukum Kewarisan Beda Agama di Indonesia Berbasis Keadilan dan Maslahah", International Journal Ihya' Ulum Al-Din 20 (2), 2018, hlm. 219.

${ }^{10}$ Maimun, "Pembagian Hak Waris terhadap Ahli Waris Beda Agama Melalui Wasiat Wajibah dalam Perspektif Hukum Kewarisan Islam”, Asas Jurnal Hukum Ekonomi Syariah 9 (1), 2017, hlm. 5.
} 


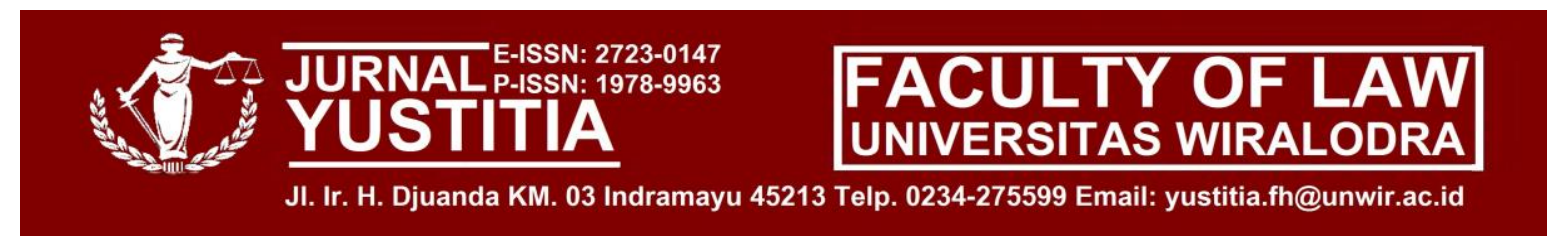

waris”. Ketentuan beragama seseorang dapat ditentukan lewat identitasnya, yang mana hal tersebut diatur dalam Pasal 172 KHI yang berbunyi: "ahli waris yang dipandang beragama Islam apabila diketahui dari kartu identitas atau pengakuan atau amalah atau kesaksian, sedangkan bayi yang baru lahir atau anak yang belum dewasa, beragama menurut ayahnya atau lingkungannya".

Ketentuan pasal-pasal KHI di atas tersebut memang tidak dinyatakan secara tegas bahwa perbedaan agama sebagai penghalang untuk dapat mewarisi, namun menurut Pasal 171 huruf c KHI tersebut menyatakan "bahwa pewaris dan ahli waris harus dalam keadaan beragama Islam maka diantara keduanya, apabila salah satunya tidak beragama Islam maka di antara keduanya tidak dapat sal i ng mewarisi, maka dalam ketentuan hak kewarisan otomatis terputus ketika berkaitan dengan perbedaan agama”.

Ketentuan dalam KHI sangat tegas bahwa "hak kewarisan otomatis terputus ketika berkaitan dengan perbedaan agama". Aturan dalam KHI tersebut mendasarkan seutuhnya pada pendapat ul ama khususnya Imam Syafi'i. Dalam hukum Islam telah diatur dengan jelas bahwasanya setiap orang yang berbeda agama tidak dapat saling mewarisi, baik orang Islam mewarisi kepada nonIslam dan juga sebaliknya. Namun dalam praktiknya, hakim di tingkat Mahkamah Agung menetapkan hak kewarisan kepada non-Muslim berdasarkan wasiat wajibah, hal ini sebagaimana yang telah diputuskan dalam Putusan Nomor 51 K/AG/1999.

Pada hakikatnya setiap manusia memiliki hak untuk menerima hak kewarisan dari orang-orang yang telah meninggal (pewaris) selama mempunyai hubungan nasab dan hubungan pernikahan dengannya. Namun ada beberapa faktor juga yang menghalangi seseorang dalam menerima hak kewarisannya yaitu: karena perbudakan, pembunuhan, dan perbedaan agama antara pewaris dengan yang meneri ma warisan.

Kedudukan anak non-muslim terhadap harta warisan pewaris beragama Islam adalah bukan sebagai ahli waris karena Hukum Waris Islam tidak mengenal adanya pewaris kepada orang yang berbeda agama (non-muslim). Hal ini yang menjadi alasan bahwa kedudukan hak anak non muslim atas warisan pewaris muslim diatur dalam Hukum Waris Islam yang berlaku di Indonesia yang menempatkan anak yang beragama lain dari agama yang dipeluk pewaris tidak memperoleh warisan tetapi memperoleh wasiat wajibah.

Dalam putusan Mahkamah Agung Nomor 5/Pdt.G/2015, Majelis Hakim menetapkan Antonius Papilaya bin Vincencius Papilaya dan Fransisca Papilaya binti 
Vincencius Papilaya selaku ahli waris anak kandung yang berbeda agama sebagai ahli waris dari almarhum Vincencius Papilaya bin Yos Papilaya. Sesuai dengan pasal 193 Kompilasi Hukum Islam (KHI), Antonius Papilaya dan Fransisca Papilaya mendapat 1/3 bagian dari harta warisan sesuai dengan putusan Mahkamah Agung Nomor 51 K/AG/1999 dengan cara wasiat wajibah.

Menetapkan Antonius Papilaya bin Vincecius Papilaya bin Vincencius Papilaya mendapat 25/72 bagian harta dari harta peninggalan (warisan) almarhum Vincencius Papilaya bin Yos Papilaya setelah dilunasi hutang-hutang almarhum Vincencus Papilaya bin Yos Papilaya. Serta menetapkan Fransisca Papilaya binti Vincencius Papilaya mendapat 25/72 bagian harta dari harta peninggalan (warisan) almarhum Vincencius Papilaya bin Yos Papilaya, setelah dilunasi hutang-hutang al marhum Vincencius Papilaya bin Yos Papilaya.

Dalam hukum Islam jelas bahwasanya setiap orang yang berbeda agama tidak dapat saling mewarisi, baik orang Islam mewarisi kepada nonIslam dan juga sebaliknya. Namun dalam praktiknya, hakim di tingkat Mahkamah Agung menetapkan hak kewarisan kepada non-Muslim berdasarkan wasiat wajibah, hal ini sebagaimana yang telah diputuskan dalam Putusan Nomor 51 K/AG/1999.

Pada hakikatnya setiap manusia memiliki hak untuk menerima hak kewarisan dari orangorang yang telah meninggal (pewaris) selama mempunyai hubungan nasab dan hubungan pernikahan dengannya. Namun ada beberapa faktor juga yang menghalangi seseorang dalam menerima hak kewarisannya yaitu: karena perbudakan, pembunuhan, dan perbedaan agama antara pewaris dengan yang meneri ma warisan.

Ada perbedaan pendapat di kalangan ulama terkait waris beda agama. Sebagian ulama mengatakan bahwa ahli waris muslim tetap mendapat harta warisan dari pewaris yang kafir. Mayoritas ulama konvensional menyikapi dua permasalahan pertama di atas telah consensus, dalam hal ini Abu Hanifah, Malik, Syafi'i, dan para pengikutnya bahwa tidak boleh orang kafir mewarisi tirkah orang muslim, atau sebaliknya, apakah disebabkan karena hubungan memerdekakan budak (alwala'), hubungan perkawinan (al-zaujiyyah), dan/atau hubungan kekerabatan (alqarabah). Demikian juga jika ada seorang muslim meni nggal dunia, ia meninggalkan seorang isteri non muslim (al-kitabiyah), atau kerabat non 


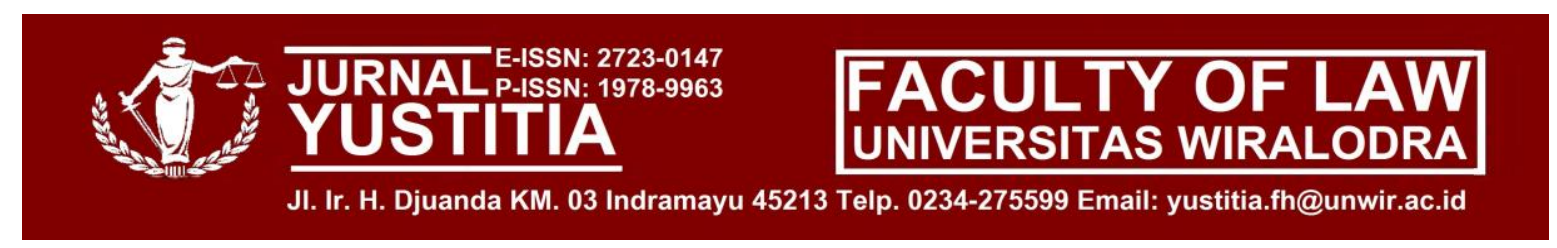

muslim kemudian mereka masuk Islam sebelum tirkah al-muwarrits dibagikan, maka mereka tetap tidak mendapatkan hak waris ${ }^{11}$.

Penghalang pewarisan atau mawani' al-irth adalah penghalang terlaksananya waris mewarisi antara pewaris dan ahli warisnya. Dalam artian lain dapat dimengerti sebagai suatu kondisi atau sifat yang menyebabkan orang tersebut tidak dapat menerima warisan padahal sudah cukup syarat-syarat dan ada hubungan pewarisan ${ }^{12}$. Penghalang waris tersebut adalah pembunuhan, perbudakan, dan perbedaan agama.

Wasiat wajibah yang diberikan Mahkamah Agung tersebut adalah untuk anak kandung non muslim. Akan tetapi, wasiat wajibah dalam Kompilasi Hukum Islam dianalogikan kepada anak angkat dan orang tua angkat. Sedangkan perbedaan agama tetap merupakan salah satu penghalang untuk dapat saling mewarisi. Pertimbangan Mahkamah Agung dalam memberikan wasiat wajibah ini adalah dengan mengusahakan suatu langkah positif dengan tidak membatasi pemahaman hukum waris selama ini.

Akan tetapi, Mahkamah Agung membuat suatu langkah melalui wasiat waj i bah bagi anggota kel uarga yang non muslim yang terhal ang mendapatkan warisannya dengan berlandaskan bahwa agama Islam bukanlah agama yang diskriminatif, tetapi Islam adalah agama yang merangkul seluruh umat di dunia. Terlepas, apapun pilihan dari individu tersebut untuk memeluk agama dan kepercayaannya masing-masing. Serta memahamkan bahwa hukum Islam tidaklah bersifat kaku. Tetapi, hukum Islam mampu memberikan perlindungan dan rasa keadilan kepada non muslim sekalipun.

\section{PENUTUP}

\section{A. Simpulan}

Pengaturan mengenai hak waris anak yang beda agama menurut hukum Islam diatur dalam hadis dan KHI yang mana anak (ahli waris) yang non muslim tidak berhak atas harta warisan. Namun pada prakteknya, dalam putusan pengadilan hakim tetap memberikan bagian harta warisan terhadap anak yang beda agama berdasarkan wasiat wajibah. Upaya penyelesaian mengenai pembagian hak waris anak yang berbeda agama menurut hukum Islam adalah dengan cara hibah dan wasiat. Hal ini sesuai dengan ketentuan Al Qur'an, hadis maupun KHI yang mana dalam hal hibah dibolehkan baik

\footnotetext{
11 Maimun, "Pembagian Hak Waris terhadap Ahli Waris Beda Agama Melalui Wasiat Wajibah dalam Perspektif Hukum Kewarisan Islam”, Asas Jurnal Hukum Ekonomi Syariah 9 (1), 2017, hlm. 5.

12 Amien Husein Nasution, Hukum Kewarisan, 78.
} 
terhadap muslim maupun non muslim. Sedangkan wasiat digunakan oleh hakim dalam putusan pengadilan terkait pembagian harta waris.

Penyelesaian sengketa kewarisan beda agama diperlukan adanya ijtihad para hakim di setiap lingkungan peradilan khususnya yang menangani masalah kewarisan. Hal ini dilakukan untuk menjawab dan menyelesaikan permasalahan kewarisan beda agama serta untuk mengisi kekosongan hukum mengenai hal tersebut. Alasan hakim di pengadilan agama melaksanakan ijtihad dalam menyelesaikan perkara kewarisan beda agama karena tidak adanya aturan hokum yang tegas mengenai hal tersebut, serta sudah menjadi kewajiban para hakim untuk menyelesaikan setiap perkara yang masuk ke pengadilan.

Salah satu hasil ijtihad para hakim yang telah memberikan kontribusi terhadap perkembangan pembaruan hukum Islam dalam hal kewarisan beda agama yaitu hasil ijtihad para majelis hakim melalui Putusan Nomor 51 K/ AG/1999 tentang perkara kewarisan beda agama dengan memberikan hak kewarisan kepada anak kandung yang beragama non-Muslim berdasarkan wasiat. Hak Waris dalam Hukum Islam kepada nonMuslim ini penting dilakukan untuk mengungkapkan permasalahan secara mendalam terkait masalah hak ahli waris non-Muslim berdasarkan wasiat wajibah.

Putusan Mahkamah Agung yang memberikan hak wasiat wajibah kepada ahli waris non muslim hanya sebagai madzab minoritas (Zhahiri) dalam khazanah pemikiran hukum Islam, namun patut kita hargai sebagai hasil penemuan hokum dalam upaya mengaktualisasikan hukum Islam di tengah-tengah masyarakat Indonesia yang pluralistik baik di bidang sosial, budaya, hukum maupun agama agar hukum Islam tidak kehilangan jati dirinya sebagi rahmatal lil'alamin. Adapun pembaharuan hukum yang dilakukan Mahkamah Agung, dalam kaitannya dengan memberikan hak wasiat wajibah kepada ahli waris non-Muslim adalah pembaharuan yang sifatnya terbatas, yaitu dengan tetap memposisikan ahli waris non-Muslim sebagai orang yang terhalang untuk mewarisi pewaris muslim sebagaimana yang telah menjadi kesepakatan para ulama (ijma).

Putusan Nomor 51 K/AG/1999 yang diputuskan pada tanggal 29 September 1999 menyatakan bahwa ahli waris yang bukan beragama Islam tetap dapat mewaris dari harta peninggalan pewaris yang beragama Islam. Pewarisan dilakukan menggunakan lembaga wasiat wajibah, dimana bagian anak kandung yang bukan beragama Islam mendapat bagian yang sama dengan bagian anak perempuan sebagai ahli waris. 


\section{B. Saran}

Pelaksanaan dalam mewujudkan hukum yang berkeadilan, berkepastian dan memiliki kemanfaatan di Indonesia seringkali hanya mementingkan aspek kepastian hokum semata, oleh karena itu sifat hukum cenderung terlihat kaku dan kurang memiliki ruh keadilan. Dalam hal pembagian waris beda agama misalnya, jika tidak mempertimbangkan aspek yang lain tentu ahli waris yang beralianan agama secara otomatis tidak mendapat bagian harta waris dari pewaris, untuk itu bagi para pelaksana penegak hokum akan lebih baik untuk memperhatikan ketiga aspek hokum tersebut, yaitu aspek keadilan, kepastian dan aspek kemanfaatan.

\section{DAFTAR PUSTAKA}

\section{A. Buku}

Abd al-Rahim, al-Muhadarat fi al-Mirast al-Muqaram, (Kairo: tp., $t$ t).

Ahmad Azhar Basyir, Hukum Waris Islam, Yogyakarta: UII Press, 2001.

Ahmad Rafiq, Fiqh Mawaris, PT. Raja Grafindo Persada, Jakarta, 1993.

Ahmad Rofiq, Hukum Perdata Islam Di Indonesia, PT Rajagrafikindo Persada, Depok, 2019.

Ahmad Rofiq, Hukum Perdata Islam Di Indonesia, PT Rajagrafindo Persada, Depok, 2019

Habsi Ash-Shiddieqy, Fiqh Mawaris, Pustaka Rizki Putra, Semarang 2001.

Muhammad Abdulkadir, Hukum dan Penelitian Hukum, PT. Citra Aditya Bakti, Bandung 2004.

Muhammad Ali Ash-Shabuni, "Pembagian Waris Menurut Islam”, Gema Insani Press, Jakarta, 1995.

Rohmawati, "Progresivitas Hukum Kewarisan Beda Agama di Indonesia Berbasis Keadilan dan Maslahah", International Journal Ihya' Ulum Al-Din 20 (2), 2018.

Sayid Sabiq, Fiqh al-Sunnah, juz 3, (Kairo, Maktabah Diar al-Turast,tt). 
Soerjono Soekanto, Pengantar Penelitian Hukum, Universitas Indonesia (UI-Press), Jakarta, 2014.

Suhaya S. Praja, Pilar-Pilar Hukum Islam, UNINUS, Bandung 1995.

Wahbah al-Zuhaili, al-Fiqh al-Islam wa Adillatubu, juz x (Dmsyk: Dar al-Fikr, 1997).

Wirjono Prodjodikoro, Hukum Waris Indonesia, Bandung: Sumur Bandung, 1991.

Zakiyah Salsabila, "Kewarisan Beda Agama menurut Hukum Waris Islam dan Hukum Waris Adat", Jurnal UIN Syarif Hidayatullah.

\section{B. Undang-Undang}

Undang-Undang Dasar Republik Indonesia 1945

Kitab Undang-Undang Hukum Perdata

Undang-Undang Nomor 3 Tahun 2006 tentang Peradilan Agama

Kompilasi Hukum Islam

\section{Sumber Lain}

Maimun, "Pembagian Hak Waris terhadap Ahli Waris Beda Agama Melalui Wasiat Wajibah dalam Perspektif Hukum Kewarisan Islam”, Asas Jurnal Hukum Ekonomi Syariah 9 (1), 2017.

Siti Nurkaerah, "Eksistensi Kompilasi Hukum Islam dalam Sistem Hukum Nasional”, Bilancia, Vol. 2, No. 2 (Juli-Desember, 2008).

www.menwih-hukum.blogspot.com “Perlakuan Waris Islam Non-Muslim”. Diakses 22 Januari 2021, pukul 21.50 WIB

Zakiyah Salsabila, "Kewarisan Beda Agama menurut Hukum Waris Islam dan Hukum Waris Adat", Jurnal UIN Syarif Hidayatullah. 